\title{
COMPARATIVE STUDY OF PHYSICOMECHANICAL PROPERTIES OF ULTRABASIC ROCKS AND ANDESITES FROM CENTRAL MACEDONIA (GREECE)
}

\author{
Petrounias P. ${ }^{1}$, Rogkala A. ${ }^{1}$, Kalpogiannaki M. ${ }^{1}$, Tsikouras B. ${ }^{1,2}$ and \\ Hatzipanagiotou K. ${ }^{1}$
}

\author{
${ }^{1}$ University of Patras, Department of Geology, Section of Earth Materials, 265 00, Patras, Greece \\ ${ }^{2}$ Universiti Brunei Darussalam, Faculty of Science, Physical and Geological Sciences, Jalan \\ Tungku Link,Gadong BE1410, Bandar Seri Begawan, Brunei Darussalam
}

\begin{abstract}
Petrographic, geochemical and physicomechanical features were determined and inter-correlated in two representative ultrabasic samples from the Veria-Naousa ophiolite and two Pliocenic andesite samples, occurring at the east of the above complex. Results show that mineralogical and textural features are major factors affecting the physicomechanical properties in both lithotypes. The ultrabasic rocks display higher resistance to attrition and abrasion and lower water absorption values relative to the intermediate volcanic rocks, hence the first are predicted to show better in-service engineering performance. However, the degree of serpentinisation is detrimental, as a highly serpentinised ultrabasic sample yielded poor results, analogous to the andesites, in certain laboratory tests. Ophiolite complexes in Greece are abundant and they are distributed along several mainland areas. Hence setting evaluation criteria for their quality is important as they can potentially replace limestones, which are less resistant and durable, in several environmental and industrial applications.
\end{abstract}

Keywords: aggregates, physicomechanical properties, andesites, serpentinite, harzburgite, ophiolite.

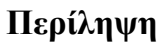

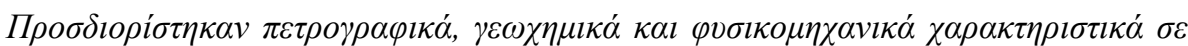

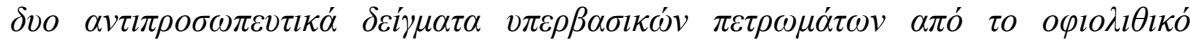

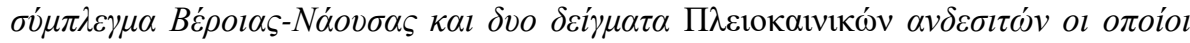

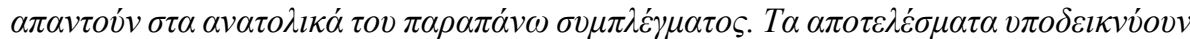

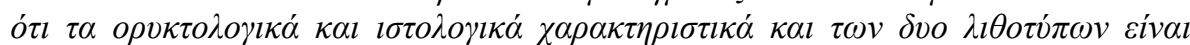

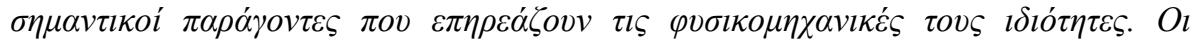

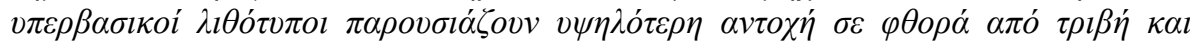

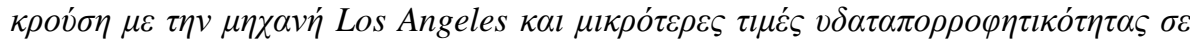

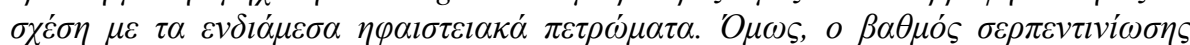

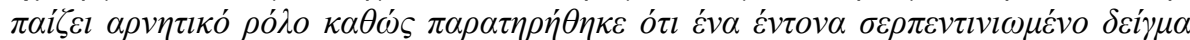

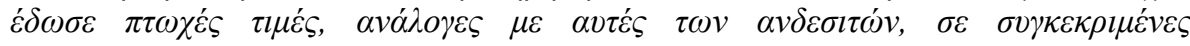

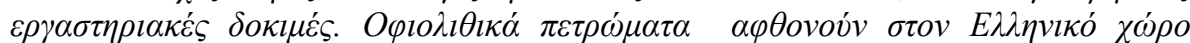

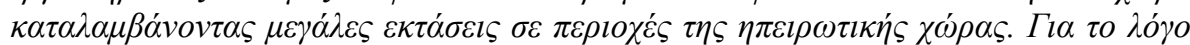

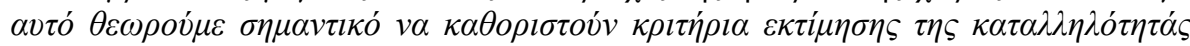




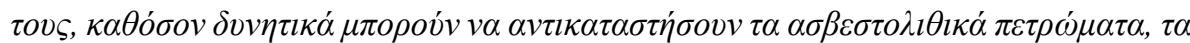

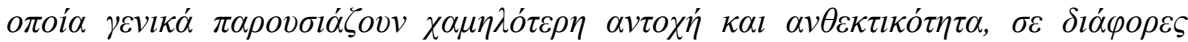

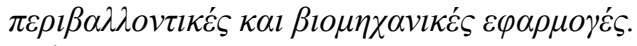

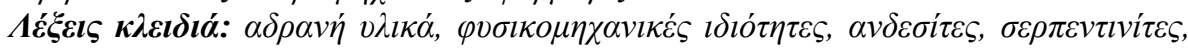

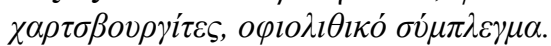

\section{Introduction}

Research of the engineering properties of ophiolitic and acidic to intermediate volcanic rocks, for industrial purposes, shows an increasing interest. Basic and ultrabasic rocks find a wide variety of uses as aggregates for antiskid road surfacing, concrete, railway ballast, etc. (French and Gammond, 1989; Tsikouras et al., 2005; Pomonis et al., 2007; Rigopoulos et al., 2010), whereas those of acidicintermediate composition comprise very good mortar aggregates for various uses (Miskovsky et al., 2004; Zorlu et al., 2004). Use of petrography as a tool in the assessment of aggregates quality dates back to the early part of the $20^{\text {th }}$ century (Knight and Knight, 1935; Griffiths, 1989; Rhoades and Mielenz, 1946). The influence of alteration on strength and durability properties of rocks has been discussed by many researchers in recent years and various micropetrographic and weathering indices have been proposed (Harben and Bates, 1990; Irfan et al., 1978; Mendes et al., 1966).

The present paper aims at the comparison of the physicomechanical properties and engineering performances of ultrabasic rocks (from the Veria-Naousa ophiolitic complex) and andesites (from a Pliocene intrusive series at the east of the complex). Moreover, we intend to investigate the influence of their petrographic characteristics to their mechanical behaviour and to assess their quality.

\section{Geological setting}

The Veria-Naousa ophiolite represents a dismembered ophiolite unit, which is superimposed on a basement consisting of rocks belonging to the Pelagonian and Axios (Almopias subzone) isopic zones in northern Greece (Fig. 1).

The ophiolite is obducted onto Cretaceous platform carbonates and a flysch succession of the Pelagonian Zone during Upper Jurassic to Lower Cretaceous time (Mercier et al., 1975; Economou, 1983; Michailidis, 1990; Economou-Eliopoulos, 2003; Tsoupas and Economou-Eliopoulos, 2008). The ophiolite suite includes, from bottom to top, serpentinised lherzolite and harzburgite, intruded by a sparse network of pyroxenitic dykes, gabbro, diabase and pillow basalts. Field work revealed that it is an incomplete and dismembered suite, due to intensive tectonism. The serpentinised peridotites are intensely tectonised, showing a dense network of joints. Rare rodingite dykes occur in the serpentinised ultramafic rocks. The ophiolite is unconformably overlain by sediments (conglomeratic limenstone, flysch).

Pliocenic volcanic rocks of the Almopias subzone ranging in composition fromtrachyte to trachyandesite occur to the east of the ophiolitic complex. $\mathrm{Nd} / \mathrm{Sr}$ isotopic data indicate that these rocks are associated with melting of the mantle wedge in supra-subduction zone regime (Eleftheriadis et al., 2003). 


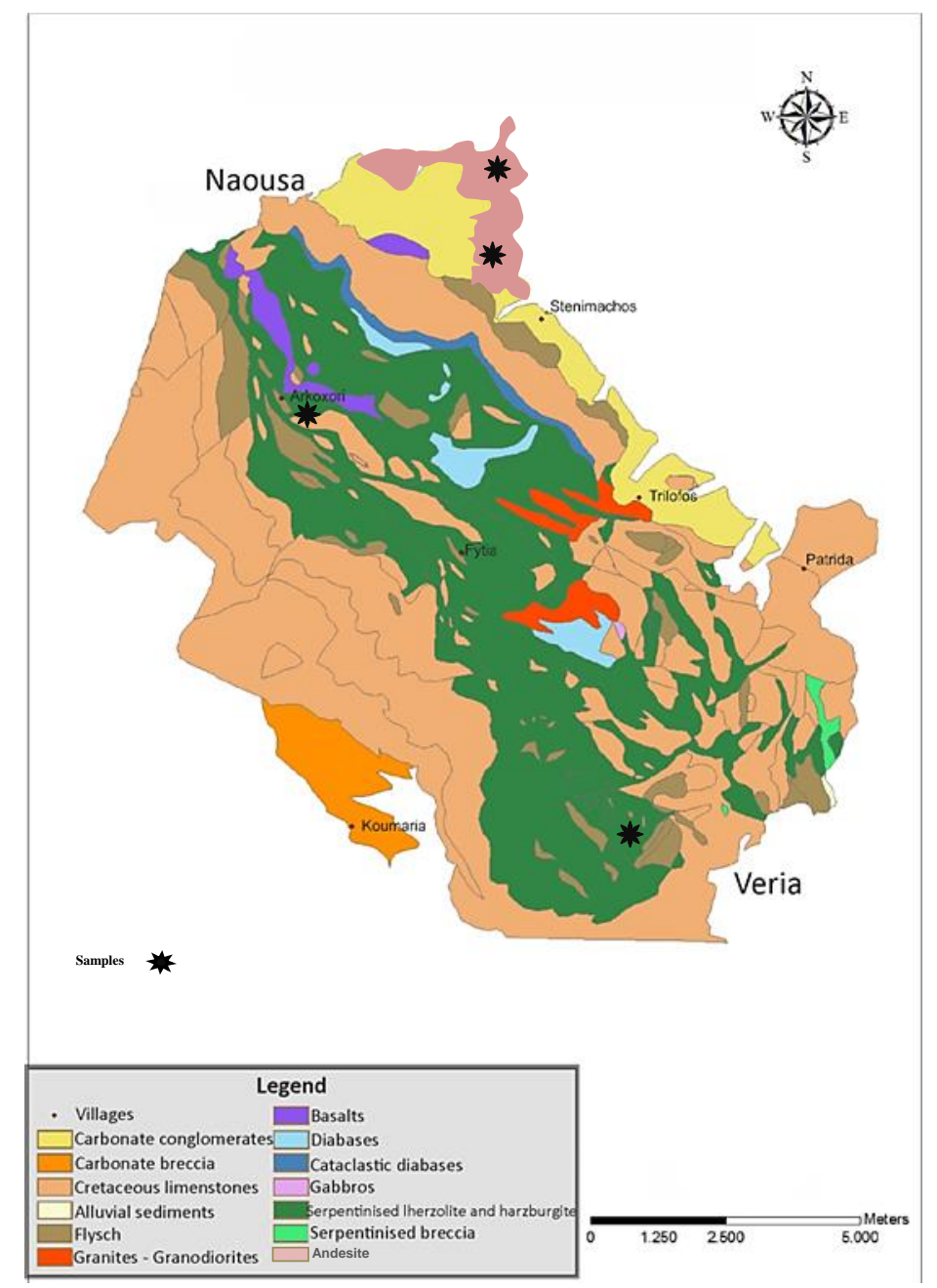

Figure 1 - Geological map of Veria-Naousa region.

\section{Analytic methods}

The mineralogical and textural characteristics of the samples were studied in polished-thin sections using polarising and scanning electron microscopes (SEM). SEM operating conditions were accelerating voltage $15 \mathrm{kV}$ and beam current $3.3 \mathrm{nA}$, with $4 \mu \mathrm{m}$ beam diameter. Whole-rock chemical analyses for major and trace elements were performed at ACME Analytical Laboratories LTD in Canada. Whole-rock major element analyses were carried out using an XRF spectrometer and a sequential spectrometer (ICP-OES). Trace elements were determined on totally digested samples by inductively coupled plasma-mass spectrometry (ICP-MS). Detection limits for major elements is $0.01 \mathrm{wt}$. \% . The analytical precision calculated from replicate analyses is better than $3 \%$ for most major elements and better than $5 \%$ for trace elements. Laboratory tests for the determination of physicomechanical properties were conducted according to international standards and included: flakiness index $\left(\mathrm{I}_{\mathrm{F}}\right.$; B5 812:105:01), moisture content (w; AASHTO T255), water absorption ( $\mathrm{w}_{\mathrm{a}}$; EAOT EN 1097-06), Los Angeles (LA; ASTM C 131), uniaxial compressive strength (USC; ASTM D 2938), Schmidt Hammer Value (SHV; ISRM 1985) and soundness (S; EAOT EN 1367-2). 


\section{Results}

\subsection{Petrographic Features}

\subsubsection{Serpentinised Harzburgite}

The serpentinised harzburgite shows mainly cataclastic texture, due to intense brittle deformation and a variety secondary textural features. Its primary modal mineralogical composition includes relics of orthopyroxene, $\mathrm{Cr}$-spinel, as well as rare olivine, and scarce clinopyroxene. Orthopyroxene appears as subhedral porphyroclasts and most of them show exsolution lamellae of clinopyroxene, typical feature of Upper Mantle peridotites. Serpentine is the major secondary phase showing typical mesh (Fig.2a, b), local bastite after orthopyroxene (Fig. 2c) and ribbon (Fig. 2d) textures. Chlorite and magnetite are also products of hydrothermal alteration of the harzburgite. Magnetite commonly fills microcracks of or rims Cr-spinel crystals. Brittle deformation is expressed mainly by intense of fragmentation of spinel as well as by intergranular microcracks.

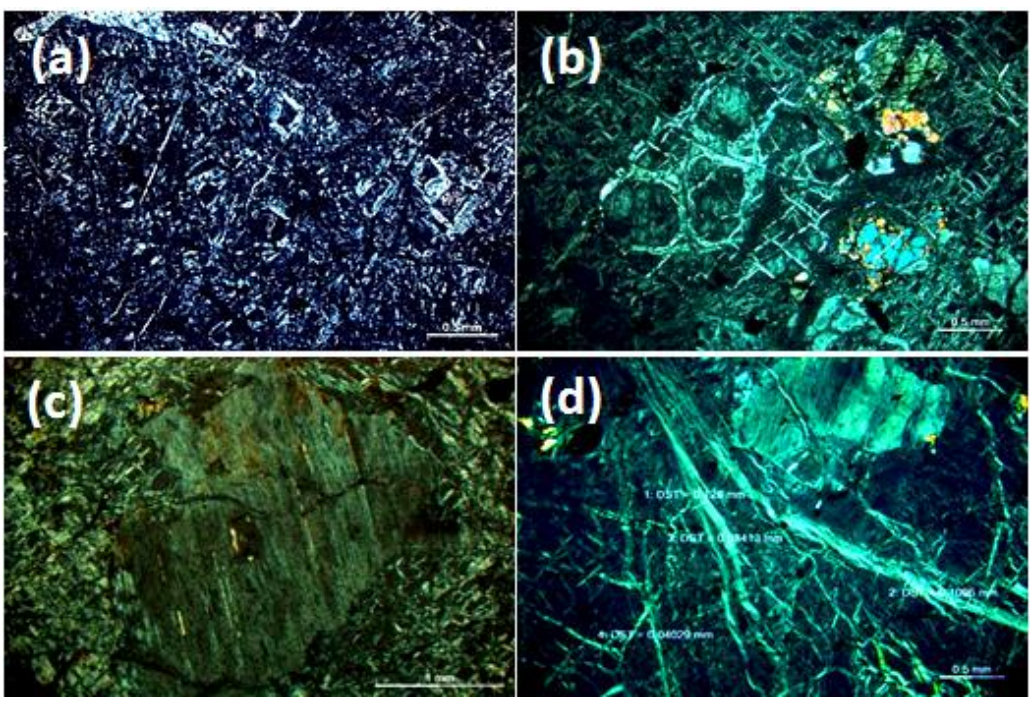

Figure 2 - Photomicrographs (XPL) of textural characteristics of the serpentinised harzburgite from the Veria-Naousa ophiolite: a and b. serpentine mess texture (samples BE.12 and BE.01, respectively), c. orthopyroxene porphyroclast with exsolution lamellae of clinopyroxene (sample BE.12), d. ribbon texture in serpentinised mass (sample BE.01).

\subsubsection{Andesite}

The collected andesite samples are vesicular and have porhyritic texture with phenocrysts of plagioclase, up to $1 \mathrm{~cm}$, biotite (rarely phlogopite) and lesser clinopyroxene surrounded by a microcrystalline and amorphous groundmass in places with flow structure (Fig. 3). Locally, plagioclase phenocrysts are surrounded by sanidine. Plagioclase phenocrysts are optically zoned showing both normal and oscillatory reverse zoning (Fig. 3c, d). Accessory minerals commonly include apatite, titanite, zircon and magnetite. Alteration products in the andesites include clay minerals, albite, chlorite, Fe-oxides and calcite. Numerous intergranular cracks are present as a result of brittle deformation. 


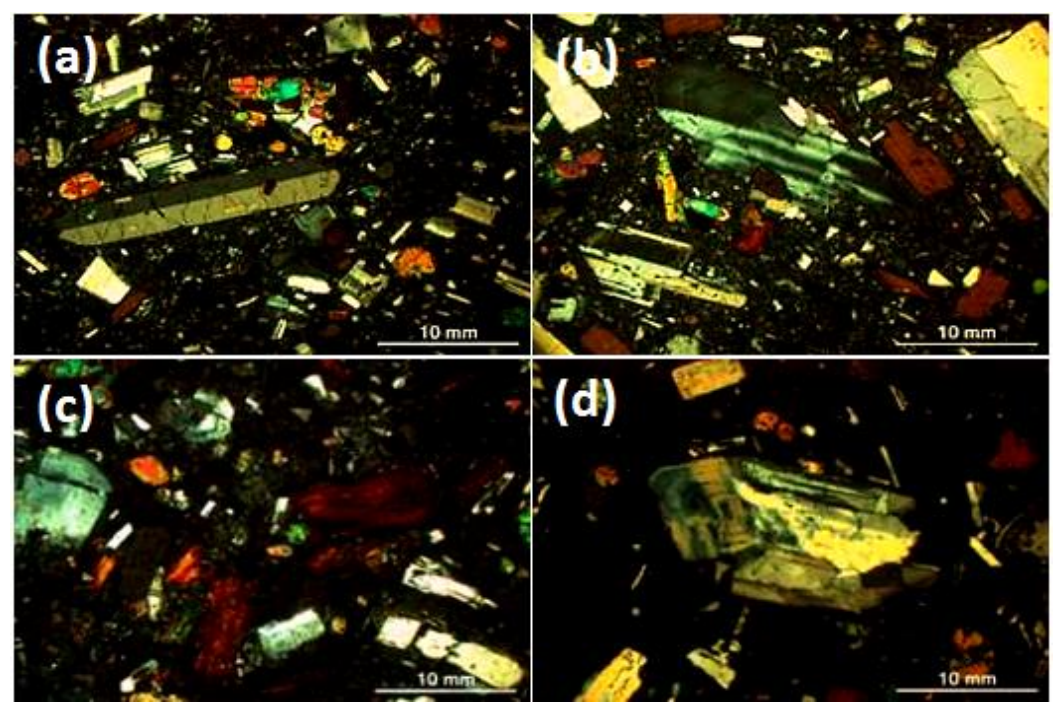

Figure 3 - Photomicrographs (XPL) of the characteristic of the Pliocene andesites from Edessa: a and b. porhyritic texture with plagioclase and clinopyroxene phenocrysts; biotite is present in b, too (sample BE.81), c. phenocrysts of oxidised biotite and zoned plagioclase in a microcrystalline to glassy groundmass (sample BE.82), d. phenocryst of a zoned and altered to albite plagioclase surrounded by glassy groundmass (sample BE.82).

\subsection{Geochemical features}

Whole-rock composition of representative andesites and ultrabasic rocks from the Veria-Naousa ophiolitic complex are listed in Table $1 . \mathrm{SiO}_{2}$ in the serpentinised harzburgites typically ranges from $39.82 \%$ to $40.95 \%$ and $\mathrm{Fe}_{2} \mathrm{O}_{3}$ from $8.06 \%$ to $8.86 \%$. The high degree of serpentinisation is reflected by high loss-on-ignition (LOI) values (13.50\%-14.60\%).

Table 1 - Whole-rock geochemical analyses of representative serpentinised harzburgites from the Veria -Naousa ophiolite and Edessa andesites.

\begin{tabular}{|c|c|c|c|c|c|c|c|c|c|}
\hline & \multicolumn{2}{|c|}{$\begin{array}{l}\text { Serpentinised } \\
\text { Harzburgite }\end{array}$} & \multicolumn{2}{|c|}{ Andesite } & & \multicolumn{2}{|c|}{$\begin{array}{l}\text { Serpentinised } \\
\text { Harzburgite }\end{array}$} & \multicolumn{2}{|c|}{ Andesite } \\
\hline & BE.01 & BE.12 & BE.81 & BE.82 & & BE.01 & BE.12 & BE.81 & BE.82 \\
\hline \multicolumn{5}{|c|}{ Major elements (wt. \%) } & \multicolumn{5}{|c|}{ Trace elements (ppm) } \\
\hline $\mathrm{SiO}_{2}$ & 39.82 & 40.95 & 60.91 & 56.39 & $\mathbf{Z n}$ & 8.00 & 26.00 & 43.00 & 26.00 \\
\hline $\mathrm{TiO}_{2}$ & * & $*$ & 0.52 & 0.63 & $\mathbf{R b}$ & 0.40 & 0.40 & 220.60 & 203.50 \\
\hline $\mathbf{A l}_{2} \mathbf{O}_{3}$ & 1.01 & 1.11 & 17.32 & $17 . ; 84$ & $\mathrm{Sr}$ & 2.00 & 0.70 & 1101.40 & 1896.20 \\
\hline $\mathrm{Fe}_{2} \mathrm{O}_{3}{ }^{\mathrm{t}}$ & 8.86 & 8.06 & 3.94 & 5.91 & $\mathbf{Y}$ & 0.90 & 33.00 & 20.10 & 27.00 \\
\hline MnO & 0.11 & 0.13 & 0.10 & 0.09 & $\mathbf{Z r}$ & 0.10 & 0.10 & 305.60 & 290.50 \\
\hline $\mathrm{MgO}$ & 34.17 & 34.81 & 1.50 & 2.25 & $\mathbf{N b}$ & 0.30 & * & 21.60 & 20.60 \\
\hline $\mathrm{CaO}$ & 0.10 & 0.21 & 3.93 & 5.28 & $\mathbf{P b}$ & 21.70 & 4.60 & 20.60 & 50.00 \\
\hline $\mathrm{Na}_{2} \mathrm{O}$ & * & * & 4.12 & 3.78 & $\mathbf{B a}$ & 1.00 & 3.00 & 1591.00 & 2020.00 \\
\hline $\mathbf{K}_{2} \mathbf{O}$ & * & * & 5.24 & 4.80 & $\mathbf{v}$ & 60.00 & 33.00 & 86.00 & 115.00 \\
\hline $\mathrm{P}_{2} \mathrm{O}_{5}$ & * & * & 0.35 & 0.39 & Sc & 11.00 & 11.00 & 8.00 & 12.00 \\
\hline LOI & 14.60 & 13.50 & 1.6 & 2.0 & $\mathbf{G a}$ & 3.10 & 3.30 & 20.40 & 20.00 \\
\hline Total & 98.67 & 98.77 & 99.53 & 99.36 & Hf & $*$ & $*$ & 7.70 & 7.40 \\
\hline \multicolumn{5}{|c|}{ Trace elements (ppm) } & Ta & * & * & 1.20 & 1.20 \\
\hline $\mathrm{Cr}$ & 2963.00 & 2792.00 & * & * & Th & * & * & 61.70 & 62.70 \\
\hline $\mathrm{Co}$ & 91.10 & 102.80 & 9.50 & 17.30 & $\mathbf{U}$ & 0.20 & * & 16.60 & 17.80 \\
\hline $\mathbf{N i}$ & 2655.80 & 2481.30 & 9.20 & 11.60 & $\mathrm{MgO} / \mathrm{FeO}^{\mathrm{t}}$ & 4.29 & 4.80 & 0.42 & 0.42 \\
\hline $\mathrm{Cu}$ & 12.90 & 7.50 & 19.70 & 29.50 & & & & & \\
\hline
\end{tabular}


The andesites show expectedly higher $\mathrm{SiO} 2$ contents $(56.39 \%-60.91 \%)$. High $\mathrm{Na} 2 \mathrm{O}, \mathrm{CaO}$ and $\mathrm{A} 12 \mathrm{O} 3$ percentages in them reflect the participation of plagioclase in these rocks. They show low loss-on-ignition (LOI) values (1.60\%-2.00\%) due to the restricted participation of hydrous minerals.

\subsection{Physicomechanical properties}

The results of the determined geometrical, physical, mechanical and physicomechanical properties from the serpentinised harzburgites and andesites are listed in Table 2. The tested peridotites are mechanically stronger than the andesites, showing higher uniaxial compressive strength (UCS), Schmidt hammer value (SHV) and lower Los Angeles (LA) values (Table 1). Soundness test (S) and water absorption $\left(\mathrm{w}_{\mathrm{a}}\right)$ values are largely different in the two ultrabasic rocks, as sample BE.01 appear much less durable and more absorbent than BE.12 (Table 2). The lower UCS and S and the higher LA values of sample BE.12 reflect its higher degree of serpentinisation relative to sample BE.01. Moisture contents (2.94\%-3.35\%) and water absorption (5.54\%-5.9\%) values are slightly higher whereas flakiness index is much lower $(15.42 \%-16.91 \%)$ in the andesites than the serpentinised harzburgites (Table 2). The two andesite samples show rather consistent $S$ values of $67.4 \%$ and $77.5 \%$, analogous to the relatively fresher peridotite sample.

Table 2 - Results of physicomechanical tests in the Veria-Naousa ultrabasic rocks and Edessa andesites.

\begin{tabular}{|c|c|c|c|c|c|c|c|c|}
\hline \multirow{2}{*}{\multicolumn{2}{|c|}{ Sample No }} & $\begin{array}{c}\text { Uniaxial } \\
\text { compression } \\
\text { strength }\end{array}$ & $\begin{array}{c}\text { Los } \\
\text { Angeles }\end{array}$ & $\begin{array}{c}\text { Schmidt } \\
\text { hammer } \\
\text { value }\end{array}$ & $\begin{array}{c}\text { Moisture } \\
\text { contect }\end{array}$ & $\begin{array}{c}\text { Water } \\
\text { absorption }\end{array}$ & $\begin{array}{c}\text { Soundness } \\
\text { test }\end{array}$ & $\begin{array}{c}\text { Flakiness } \\
\text { index }\end{array}$ \\
\hline & & $U C S(M p a)$ & $L A(\%)$ & SHV & $W(\%)$ & $W_{o}(\%)$ & $S(\%)$ & $I_{F}(\%)$ \\
\hline \multirow{2}{*}{$\begin{array}{c}\text { Serpendinised } \\
\text { harzburgite }\end{array}$} & BE.01 & 75.62 & 19.20 & 60.90 & 2.58 & 4.40 & 75.34 & 42.10 \\
\hline & BE.12 & 56.40 & 25.16 & 60.00 & 2.18 & 1.68 & 18.05 & 37.20 \\
\hline \multirow{2}{*}{ Andesite } & BE.81 & 34.52 & 37.93 & 49.00 & 2.94 & 5.90 & 77.50 & 15.42 \\
\hline & BE.82 & 35.62 & 39.41 & 50.30 & 3.35 & 5.54 & 67.40 & 16.91 \\
\hline
\end{tabular}

\subsection{Correlations of physicomechanical properties}

Regression and factor analyses were applied to test the acquired results and to detect the interrelationships between their geometrical, physical and mechanical properties (Fig.4). Evidently, the two different rock-types cluster at different areas on the correlation diagrams, apparently due to their considerably dissimilar values in certain tests. Decoupling of the ultrabasic samples in some diagrams results from their different strength and durability, owed to the different degree of serpentinisation. However, all samples form cohesive trends that can be described by statistical equations and important correlations can be obtained.

Linear regression was used based on the linearity assumption and the determination coefficients $\mathrm{R}^{2}$ and equations of the fitted lines were calculated by the "least squares" method. Other types of relationships were also tested (e.g. logarithmic, power, etc.) but it is always observed that the linear model fits best, giving the highest $\mathrm{R}^{2}$ values. Uniaxial compression strength and Schmidt hammer 
value show excellent negative linear correlations with Los Angeles coefficient (Fig. 4a, b), which can be described by the equations:

$$
\begin{aligned}
& \mathrm{UCS}=-1.9488 \times \mathrm{LA}+109.83, \mathrm{R}^{2}=0.9665 \\
& \mathrm{SHV}=-0.6184 \times \mathrm{LA}+73.864, \mathrm{R}^{2}=0.9432
\end{aligned}
$$

Los Angeles shows excellent negative and good positive linear correlations with Flakiness index and moisture content, respectively (Fig. 4c, d) and these relationships can be modelled with the following equations:

$$
\begin{gathered}
\mathrm{LA}=-0.7097 \times \mathrm{I}_{\mathrm{F}}+50.232, \mathrm{R}^{2}=0.9782 \\
\mathrm{LA}=15.65 \times \mathrm{W}-12.808, \mathrm{R}^{2}=0.6311
\end{gathered}
$$

Soundness test demonstrate an excellent positive linear relationship with water absorption (Fig. 4e), which can be described by the equation:

$$
\mathrm{S}=13.589 \times \mathrm{W}_{\mathrm{a}}+0.0506, \mathrm{R}^{2}=0.8582
$$

Flakiness index shows an excellent positive linear relationship with uniaxial compressive strength (Fig. 4f) and the relationship is given by the equation:

$$
\mathrm{I}_{\mathrm{F}}=0.6779 \times \mathrm{UCS}-6.3523, \mathrm{R}^{2}=0.9298
$$

(a)

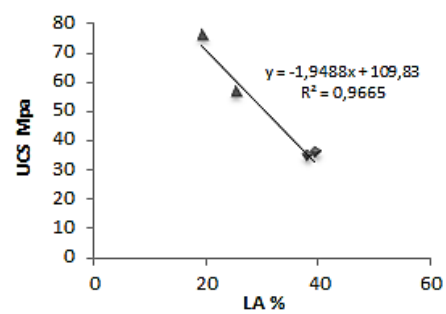

(c)

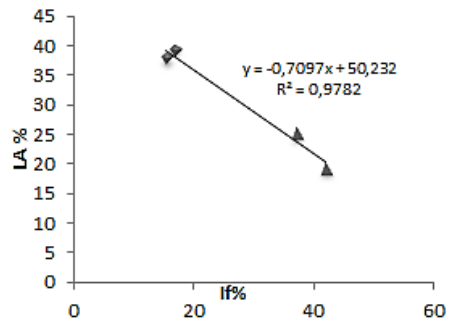

(e)

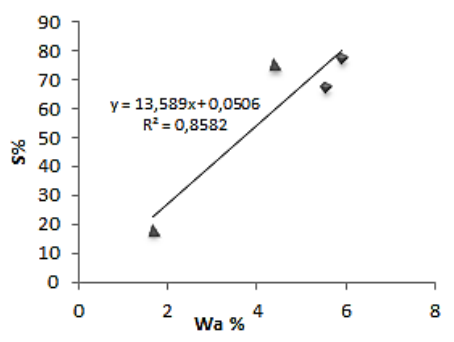

(b)

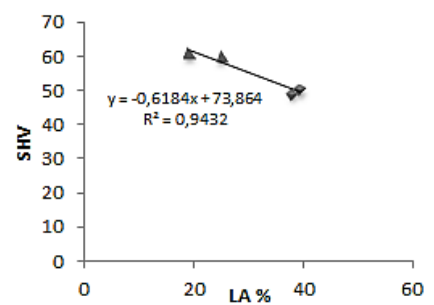

(d)
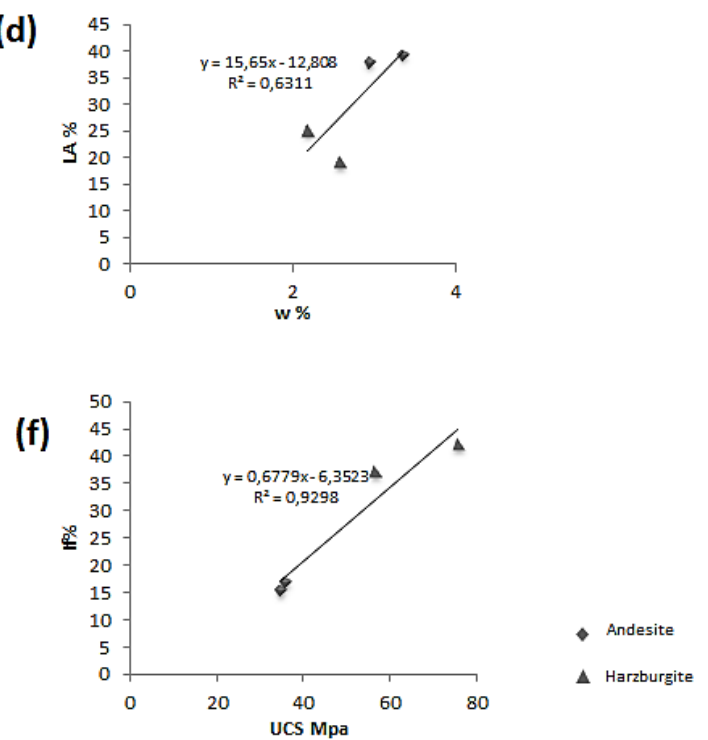

Figure 4 - Correlations of physicomechanical properties of the ultrabasic rocks from the Veria-Naousa ophiolite and the Edessa andesites. 


\section{Discussion}

\subsection{The Influence of Alteration on the Engineering Properties of the Rocks}

Mineralogical composition, textural features, degree of alteration/deformation and weathering are the main factors which affect the physicomechanical properties and consequently the suitability of aggregates in industrial applications (Hartley, 1974; Brattli, 1992). Primary assemblages of ultramafic rocks are often converted to secondary mineral phases as a result of ocean-floor metamorphic process. Ocean-floor metamorphism has variably affected the collected ultrabasic samples and despite the fact that we present a limited number of samples, it is evident that serpentinisation has a negative influence on the engineering behaviour of these rocks, as sample BE.12 is clearly weaker and less durable relative to the less serpentinised sample BE.01; similar results have been previously proposed by other authors, too (Rigopoulos et al., 2010; Smith and Collins, 2001). The much lower hardness of the secondary minerals (serpentine polymorphs and chlorite) relative to the primary relics (olive and pyroxenes) results in differential mechanical behaviours, thus contributing to the weakness and easier deterioration of the rocks under stress and subsequently during their in-service. This is assigned to the fact that the secondary minerals have substantially different mechanical behaviour compared with the primary ones, leading to a modification of rock strength (Rigopoulos et al., 2010).

The andesites include secondary clay minerals as a result of plagioclase alteration. These clay minerals have the ability to absorb water within their structure, therefore, even present in low amounts, they contribute to the disintegration and low coherence of the rocks. The andesites have been greatly affected by brittle deformation, as it is deduced by a dense network of cracks and joints in their mass. This feature along with their vesicular structure are considered as the main factors for their reduced strength and durability relative to the significantly altered serpentinised harzburgites.

\subsection{Interdependence of Physicomechanical Properties}

Regression analysis indicate significant interrelationships between the physicomechanical properties in both the ultrabasic and andesitic rocks. Inverse correlation of LA with UCS and SHV, suggest that the resistance of these rocks in attrition and grinding is a linear function of their strength. Similar correlations have been previously reported for mafic and ultramafic rocks, too (Rigopoulos et al., 2006; Rigopoulos et al., 2009; Davis, 2002; Räisänen, 2004) but from this research it is concluded that such a relationship can be extended to other rock types like intermediate volcanic rocks.

The flakiness index is a critical factor for the quality of aggregates as flaky particles may have adverse effects in several applications and impair the durability of constructions. The significantly higher $\mathrm{I}_{\mathrm{F}}$ of the serpentinised samples can be explained by the large amount of secondary serpentine and chlorite (both of the phyllosilicate subclass) thus affecting their intrinsic mechanical properties. The andesites, which contain mostly prismatic and squat crystals as well as glass and lack abundant phyllosilicate minerals exhibit better $I_{F}$ values. However, this coefficient shows a negative correlation with LA and a positive one with UCS suggesting that the adverse influence of the flaky shape of the aggregates is surpassed by other factors and most likely the mineralogical composition and texture as well as the brittle deformation of the rocks; the last appears to have a stronger influence on the quality of the aggregates.

Water absorption and moisture content are two parameters that are commonly considered to relate with open pores and the presence of minerals that have the capability to sequester water (like serpentine, chlorite and clay minerals). The positive correlations of $\mathrm{S}$ and LA with $\mathrm{w}_{\mathrm{a}}$ and $\mathrm{w}$, respectively, can be interpreted that open spaces (voids and/or joints) are detrimental to the mechanical strength and durability of both the ultrabasic and andesitic rocks. The later contain much lesser amounts of clay minerals than the amount of serpentine (and chlorite) in the ultrabasic lithologies, therefore it is plausible to assume that porosity and fracturing is a more important factor 
than the presence of water adsorbing minerals. These open spaces accommodate water and can host the crystallisation of salts, which are well-known disadvantageous factors for the engineering performance of rocks.

\section{Conclusions}

Ultrabasic and andesitic lithologies were studied and significant relationships are found between them. The ultrabasic rocks are variably serpentinised, a feature that influences negatively their performance. The sheet-like and soft character of the secondary minerals, as well as the coexistence of harder primary minerals contribute to the disintegration of the altered peridotites. Although the andesites show smaller degree of alteration, their tectonic disturbance and high porosity are extremely a negative factors for their in-service performance, contributed by the minor occurrence of secondary clay minerals, too. These factors cause a dramatic deterioration of their strength and durability as aggregates, hence the andesites show eventually worse engineering properties than the serpentinised peridotites. These low quality andesites are considered unsuitable for most industrial and construction applications, however they may be suitable for the production of mortars where high $\mathrm{w}$ and $\mathrm{w}_{\mathrm{a}}$ values are favoured. The significant correlations observed between several physicomechanical parameters suggest the strong interdependence of these properties in a broad range of lithologies, like peridotites and andesites. Certain coefficients can be predicted from others and their determination coupled with petrographic information can assist to the explanation of the engineering behaviour of the rocks.

\section{References}

Brattli, B., 1992. The influence of geological factors on the mechanical properties of basic igneous rocks used as road surface aggregates. Eng. Geol., 33:31-44.

Davis, G.H., 2002, Tentative correlation between the pl(pla-gioclase) normin and L.A. Wear Percent in Precambrian mid-continent granites [abs.], In: Seeger, C.M., eds., Forum on the Geology of Industrial Minerals, 38th, St. Louis, Mo, Proceedings: Jefferson City, Missouri Division of Geology and Land Survey, 48 pp.

Economou, M., 1983. A short note on the evolution of the Vermion ophiolite complex (MacedoniaGreece), Ofioliti, 8, 333-338.

Economou-Eliopoulos, M., 2003. Apatite and Mn, Zn, Co-enriched chromite in Ni-laterites of northern Greece and their genetic significance, Journal of Geochemical Exploration, 80, 41-54.

Griffiths, J., 1989. Olivine, volume the key to success, Ind. Minerals, 1, 25-36.

Harben, P.W. and Bates, R.L., 1990. Industrial minerals, geology and world deposits, London: Industrial Minerals Division, metal Bulletin Plc., 312.

Eleftheriadis, G., Castorina, F., Soldatos, T. and Masi, U., 2003. Geochemical and Sr-Nd isotopic evidence for the genesis of the Late Cainozoic Almopia Volcanic rocks (Central Macedonia, Greece), Miner. Petrol., 78, 21-36.

Hartley, A., 1974. A review of the geological factors influencing the mechanical properties of road surface aggregates, Quaterly Journal of Eng. Geol., 7, 69-100.

Irfan, T.Y. and Dearman, W.R., 1978. The engineering petrography of a weathered granite in Cornwall, England, Q. J. Eng. Geol., 11, 233-44.

Knight, B.H. and Knight, R.G., 1935. Road aggregates, their uses and testing. London, Edward Arnold.

Miskovsky, K., Taborda Duarte, M., Kou, S.Q. and Lindqvist, P.A., 2004. Influence of the mineralogical composition and textural properties on the quality of coarse aggregates, $J$. Mater. Eng. Perform., 13, 144-150.

Mendes, F.M., Aires-Barros, L. and Rodrigues, FP., 1966. The use of modal analysis in the mechanical characterization of rock masses. In: Proccedings of first congress, international society for rock mechanics, Lisbon, 217-233. 
Mercier, J., Vergely, P. and Bebien, J., 1975. Les ophiolites helleniques "obductees" au Jurassique superieur sont-elles les vestiges d' un ocean tethysien ou d' une mer marginale perieuropeenne. C.R. Somm. Soc. Geol., France, 17, 108-112.

Michailidis, K.M., 1990. Zoned chromites with high Mn-contents in the Fe-Ni-Cr-laterite ore deposits from the Edessa area in Northern Greece, Mineral. Deposita, 25, 190-197.

Pomonis, P., Rigopoulos, I., Tsikouras, B. and Hatzipanagiotou, K. 2007. Relationships between petrographic and physicomechanical properties of basic igneous rocks from the Pindos ophiolitic complex, NW Greece, Bull. Geol. Soc. Greece, 40, 947-958.

Räisänen, M., 2004. Relationships between texture and mechanical properties of hybrid rocks from the Jaala-litti complex, southeastern Finland, Eng. Geol., 74, 197-211.

Rhoades, R. and Mielenz, R.C., 1946. Petrography of concrete aggregate, Proc Am Concr Inst., 42, 581-600.

Rigopoulos, I., Tsikouras, B., Pomonis, P. and Hatzipanagiotou, K. 2006. Comparative Evaluation of Dolerites from the Pindos and Vourinos Ophiolitic Rocks for their Use as Aggregates, Tech. cron. Sci. J. TCG, I, No3.

Rigopoulos, I., 2009. Correlation between petrographic and physico-mechanical properties of the Pindos and Vourinos ophiolitic rocks and assessment of their suitability as aggregates in construction-industrial uses, $\mathrm{PhD}$ thesis, University of Patras.

Rigopoulos, I., Tsikouras, B., Pomonis, P. and Hatzipanagiotou, K., 2010. The influence of alteration on the engineering properties of dolerites: the examples from the Pindos and Vourinos ophiolites (northern Greece), Int. J. Rock Mech. Min. Sci., 47, 69-80.

Smith, M.R. and Collis, L., 2001. Aggregates: sand, gravel and crushed rock aggregates for construction purposes, Spec. Publ., 17, Geol. Soc. London.

Tsikouras, B., Pomonis, P., Rigopoulos, I. and Hatzipanagiotou, K., 2005. Investigation for the suitability of basic rocks from Mikrokleisoura, Grevena, for their use as antiskid aggregates and railway ballast, Proc. 2nd Congress of Committee of Economic Geology, Mineralogy, and Geochemistry of the Geological Society of Greece, 347-356

Tsouras, G. and Economou-Eliopoulos, M., 2008. High PGE contents and extremely abundant PGEminerals hosted in chromitites from the Veria ophiolite complex, Northern Greece, Ore Geol. Rev., 33, 3-19.

Tugrul, A. and Gurpinar, O., 1997. The effect of chemical weathering on the engineering properties of Eocene basalts in northeastern Turkey, Environ. Eng. Geosci., 3, 225-34.

Zorlu, K., Ulusay, R., Ocakoglu, F., Gokceoglou, C. and Sonmez, H., 2004. Predicting intact rock properties of selected sandstones using petrographic thin-selection data, Int. J. Rock Mech. Min. Sci., 41(1), 93-98. 